Discussion Paper No. 12-031

\title{
Students' E-skills, Organizational Change and Diversity of Learning Processs: \\ Evidence from French Universities in 2010
}

Adel Ben Youssef, Mounir Dahmani, and Nessrine Omrani

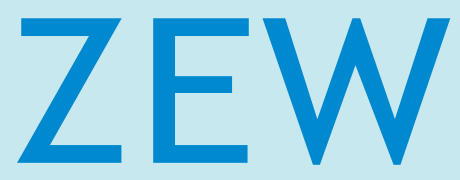

Zentrum für Europäische Wirtschaftsforschung $\mathrm{GmbH}$

Centre for European

Economic Research 
Discussion Paper No. 12-031

\title{
Students' E-skills, Organizational Change and Diversity of Learning Processs: Evidence from French Universities in 2010
}

\author{
Adel Ben Youssef, Mounir Dahmani, \\ and Nessrine Omrani
}

Download this ZEW Discussion Paper from our ftp server:

http://ftp.zew.de/pub/zew-docs/dp/dp12031.pdf

Die Discussion Papers dienen einer möglichst schnellen Verbreitung von neueren Forschungsarbeiten des ZEW. Die Beiträge liegen in alleiniger Verantwortung der Autoren und stellen nicht notwendigerweise die Meinung des ZEW dar.

Discussion Papers are intended to make results of ZEW research promptly available to other economists in order to encourage discussion and suggestions for revisions. The authors are solely responsible for the contents which do not necessarily represent the opinion of the ZEW. 


\section{Non-Technical Summary}

Information and communication technologies (ICT) play a crucial role in higher education. They modify the scope, the borders and the content of learning. Most of European Universities try to change their pedagogical concepts in order to face the challenges of efficiently integrating ICT in their curricula.

One key result in integrating ICT in higher education is the fact that students acquire new e-skills and further develop their initial ones. By eskills we refer to the ability to efficiently and critically use ICT. At least four layers of students' e-skills are identified: Operational e-skills imply that students know how to operate a computer. With formal e-skills students additionally use some basic Internet applications. Students who also use ICT tools for learning purposes are supposed to have information e-skills. Finally, strategic e-skills, which are the most advanced, refer to students who use ICT intensively in order to collaborate with others.

Our article claims that organizational changes at European Universities are a necessary condition in order to equip students with high levels of e-skills.

We have analysed this hypothesis for French Universities and we have found a strong correlation between the implementation of a "student-centred model of learning" or "active way of learning" and students' levels of e-skills. More precisely, three main results were obtained:

Firstly, students' involvement in using ICT enhances students' operational e-skills. ICT training enhances students' information e-skills. Students who spend more time surfing on the Internet have more sophisticated e-skills.

Secondly, the diversity of learning processes enhances the accumulation of students' e-skills. Thirdly, collaborative and cooperative learning facilitates the accumulation of students' strategic e-skills. 


\section{Das Wichtigste in Kürze}

Informations- und Kommunikationstechnologien (IKT) spielen eine herausragende Rolle in der Hochschulbildung. Sie können die Möglichkeiten, Grenzen, sowie die Lehrinhalte der Bildung verändern. Die Mehrheit der Europäischen Universitäten versucht, ihre pädagogischen Konzepte dahingehend anzupassen, IKT bestmöglich in die Lehrpläne zu integrieren.

Eines der wichtigsten Ziele dieser Politik ist, dass Studenten sowohl neue IKT-Fähigkeiten erwerben als auch ihre bisherigen Kenntnisse erweitern. Wir identifizieren vier Ebenen von IKT-Fähigkeiten der Studenten: „Operationale IKT-Fähigkeiten" beziehen sich auf das einfache Bedienen eines Computers. Mit „Formalen IKT-Fähigkeiten“ verwenden Studierende elementare Internet-Anwendungen. Studierende, die IKT-Anwendungen zusätzlich zum Lernen verwenden, verfügen über „IKT-Fähigkeiten zur Informationsgewinnung“. Schließlich bezeichnen „Strategische IKT-Fähigkeiten“ die intensive Nutzung von IKT insbesondere zur Kollaboration.

In unserem Artikel argumentieren wir, dass an europäischen Universitäten organisatorische Veränderungen eine Voraussetzung für die Verbesserung der IKT-Fähigkeiten von Studierenden sind. Wir untersuchen diese Hypothese für Studierende von drei französischen Universitäten und finden eine starke Korrelation zwischen den IKT-Fähigkeiten der Studierenden und der Einführung eines ,Student-Centred Model of Learning“. Insbesondere liefert die Studie folgende Erkenntnisse: Der Umgang mit IKT fördert die operationalen IKT-Fähigkeiten. IKT-Weiterbildung verbessert die IKT-Fähigkeiten zur Informationsgewinnung. Studierende, die mehr Zeit im Internet verbringen, haben fortgeschrittene IKT-Fähigkeiten. Zudem führt eine Diversifizierung der Lernprozesse zu verbessertem Erwerb von IKT-Fähigkeiten. Schließlich vereinfacht kooperatives Lernen die Generierung von strategischen IKT-Fähigkeiten. 


\title{
Students' e-skills, organizational change and diversity of learning process: Evidence from French universities in $2010^{\text {th }}$
}

\author{
Adel Ben Youssef ${ }^{\mathrm{a}, *}$, Mounir Dahmani ${ }^{\mathrm{b}}$, Nessrine Omrani ${ }^{\mathrm{c}}$ \\ ${ }^{a}$ GREDEG-CNRS, University of Nice Sophia Antipolis, France \\ ${ }^{b}$ PREG-CRG, Ecole Polytechnique of Paris, France \\ ${ }^{c}$ ADIS, University of Paris Sud, France
}

May 2012

\begin{abstract}
Driven by ICT, universities are changing in depth the nature and forms of learning processes, which are intended to prepare students to a better entry into the labour market. In this paper, we focus on the evolution of students' use of ICT in such an institution characterized by organizational changes and we analyse the determinants of students' e-skills using a 2010 dataset of French university students. We show that students' involvement in the use of ICT increases their e-skills. ICT learning by doing and ICT learning by using also increase some categories of students' e-skills. In addition, collaborative and cooperative learning are positively associated with students' advanced e-skills.
\end{abstract}

Keywords: Students, ICT, E-skills, Multinomial logit model, labour market, New Organizational Practices.

\footnotetext{
Acknowledgements: We would like to thank Irene Bertschek, Daniel Erdsiek, Jim Hough, Martin Peitz, Ludovic Ragni, and the participants of the ZEW seminar held in Manheim (ZEW, December 12, 2011) and the Seminar of ENST Paris held in Paris (ParisTech, November 17, 2011) for their helpful comments on an earlier version of this work.

*Corresponding author. GREDEG, 250 rue Albert Einstein, Bat 2, 06560 Valbonne. Tel: +33(0)493954228 - Fax +33(0)493653798.

Email addresses: adel.ben-youssef@unice.fr (Adel Ben Youssef), mounir.dahmani@polytechnique.edu (Mounir Dahmani), nessrine.omrani@u-psud.fr (Nessrine Omrani)
} 


\section{Introduction}

Advances in Information and Communication Technologies (ICT) have dramatically transformed the work place during the past two decades. The basic requirements of education for future employment have changed since knowledge became the most critical resource for social and economic development (Hakkarainen et al., 2000). Ability to use computer and Internet effectively, a qualified education, and communication skills can be seen as prerequisites for white-collar jobs.

Universities have invested significantly in ICT equipment during the past two decades (OECD, 2006). ICT use is supposed to improve the educational output and, thus, the quality of higher education. Many researchers have shown that ICT use leads to an improved academic performance (measured by the success in exams and achievements, Hoskins and van Hooff, 2005; van Dijk, 2006; Rivkin et al., 2005; Su, 2008; Tuparovaa and Tuparova, 2010). In addition, it has been claimed that using ICT in Higher Education facilitates e-skills' acquisition by students. In sum, ICT use improves the students' prospects in the labour market. For the U.S., it has been reported that Internet use at universities has led to an increase of ICT use in the whole US economy (Goldfarb, 2006). In the European Union, a strategy was put in place to improve the e-skills of the labour force (Fonstad and Lanvin, 2009; Kolding and Kroa, 2007). While an extensive literature has discussed the academic performances of students associated with ICT usage (Angrist and Lavy, 2002; Banerjee et al., 2007; Lundberg et al., 2008; Machin et al., 2007), the effect on skills acquisition appears to be underexplored.

Understanding successful use of ICT in higher education and its implications is of high practical relevance. It is important for long-term strategic pedagogical planning of technology implementation in education (Jonassen et al., 2005; Nicol and MacLeod, 2005) as it affects the engagement of students in active learning and problem solving through ICT (Barak et al., 2006).

In recent years, a debate has intensified about the process of organizational change at the institutional level and how it is needed because higher education is being asked to be responsive to an ever-changing environment (Kezar, 2001). With respect to the debate about the productivity paradox ${ }^{1}$, performance associated with ICT usage depends strongly on the adoption of New Organizational Practices (NOP) (Greenan and Mairesse, 2004; Greenan and Walkowiak, 2006). During the last decade, many firms have experienced a reorganization of their workplace. New work practices have been adopted

\footnotetext{
${ }^{1}$ For detailed explanation of the productivity paradox see the paper of Triplett, 1999.
} 
such as job rotation, delayering, self-directed work-team, just-in-time and total quality management (Askenazy et al., 2002). Ichniowski et al., 1997; Black and Lynch, 2001b; Caroli and Van Reenen, 2001 find a positive impact of new work practices on productivity especially in connection with information technologies ${ }^{2}$. According to Arvanitis and Loukis, 2009, ICT, new organizational practices and human capital can contribute to firm efficiency and performance.

As exemplified above, empirical research is mostly devoted to industry, few empirical works analyse the adoption of new organizational practices at universities and their impacts on the learning processes and the outputs of higher education. In the European Union, the SEUSISS Project Final Report, 2003 suggests that university students learn, develop or "pick up" their ICT skills from a variety of formal and informal sources. This includes formal training sessions at school or college and informal tuition from friends, family or peers as well as self-teaching with or without the help of user manuals.

In order to understand how to assess the impact of organizational change in higher education institutions on high-performance e-skills it's useful to understand how they are acquired. Taking into account that the student' eskills acquisition process may be the result of their educational, professional or personal experiences, the possibility of reverse causality is hard to exclude. However, there is only weak evidence that initial student ICT skill deficiencies have a significant negative effect on the use of ICT. Additionally, the fact that the students in our sample have had essentially identical classroom experiences throughout their lives and are well equipped with ICT resources casts doubt on explanations based on heterogeneity in intensity of ICT use are essentially due to student's initial e-skills level. In fact, we claim that e-skills acquisition and maintain the accumulation require a significant organizational change in higher education institutions (collaboration, innovativeness, teacher-student interaction outside the class...), diversity of learning processes (learning by doing, learning by using, and learning by failing), and an important investment by students (measured by time spent surfing on the Internet, and ICT trainings). The aim of this paper is explore the correlation between organizational change and the e-skills levels of students. We argue that the adoption of French Universities of new organizational changes is improving the students' e-skills. The aim of this paper is explore the corre-

\footnotetext{
${ }^{2}$ Black and Lynch, 2001a; Askenazy and Gianella, 2000 and Bresnahan et al., 2002 underline the importance of introducing clusters of complementary practices. New work practices are biased against unskilled labour leading to an upskilling of firms' occupational structure (Askenazy, 2000; Greenan, 1996; Caroli and Van Reenen, 2001).
} 
lation between organizational change and the e-skills levels of students. We argue that the adoption of French Universities of new organizational changes is improving the students' e-skills.

The structure of the paper is the following: Section 2 discusses the research background and the related literature. Section 3 introduces the data, the variables and the econometric methodology. Section 4 presents the results and discusses the main findings. Section 5 gives conclusions.

\section{Research background: ICT, NOP and e-skills}

This section is dedicated to the discussion of the research background. Firstly, we clarify the debate about e-skills and our chosen definition. Secondly, we present the different means by which organizational changes within universities may impact their e-skills. Three complementary channels of organizational change are discussed: behavioural change of students induced by organizational change, strategies for diversifying the learning mechanisms and collaborative learning.

\subsection{E-skills}

Steyaert, 2002 provides a classification of e-skills. He distinguishes between instrumental e-skills, i.e., the operational manipulation of technology, operational e-skills, i.e., the structure in which information is contained, and strategic e-skills, i.e., the basic readiness to pro-actively look for information, information-based decision-making and scanning of the environment for relevant information.

Concerning structure, it is not clear whether these skills are only a prospect understanding of ICT tools or, in addition, include the identification of the information. van Dijk, 2005 modifies Steyeart's definition. He distinguishes between operational, information, and strategic e-skills. Operational skills are the skills to operate computer and network hardware and software and can be seen as equivalent to instrumental e-skills. Information skills are the skills to search, select, and process information in computer and network sources. This skill category is subdivided into formal information skills (the ability to understand and to handle the formal characteristics of a computer and a computer network such as file structures, menu structures, and hyperlinks) and substantial information skills (the ability to find, select, process, and evaluate information in specific sources of computers and networks according to specific questions and needs). And finally strategic e-skills are the capacities to use these sources as the means for specific goals and for the general goal of improving one's position in society, which corresponds to Steyeart's classification. 
van Deursen and van Dijk, 2010, instead of considering formal information skills and substantial information skills as subcategories of information skills, introduce formal skills for the former and information skills for the latter as two separate categories. While formal skills strongly relate to the characteristics of digital technology, information skills together with strategic skills relate to the content provided by ICT tools. They distinguish between (1) operational skills as the skills to operate digital media, (2) formal skills as the skills to handle the structures of digital media, and (3) information skills as the skills to locate information in digital media and (4) strategic skills as the skills to employ the information contained in digital media towards personal and professional development.

We adopt in our paper the definition of e-skills by van Deursen and van Dijk, 2010. Students' e-skills are divided into four categories starting from the basic e-skills (operational e-skills) to the more advanced ones (strategic e-skills), which are based on collaborative work. Students who only have operational e-skills tend to be the later adopters of ICT. They only have skills to operate a computer. They do not use ICT intensively and do not use them for collaborative work. Then, regarding formal e-skills, students in this category, in addition to operational e-skills, use some basic Internet applications. Concerning students who have the third category of e-skills (information e-skills) they use ICT as tools for learning purposes in addition to the two first categories. Finally, strategic e-skills, which are the most advanced, include students who are early adopters of ICT. These students use ICT intensively in order to collaborate with others.

\subsection{How do organizational changes within university relate to students' $e$ - skills?}

The central question of our article is to look how NOP is related to the development of student's e-skills. Our basic idea is that for effective ICT use, universities have to explore new forms of learning and students have to develop new attitudes. These forms of learning and attitudes are not developed by the classical way of teaching within universities. The use of ICT combined with the classical way of learning does not fully exploit the potential of students' ICT use. Changes in the organization of classrooms and the way of teaching improve the performance of those students who acquire more e-competencies. According to Arvanitis and Loukis, 2009, the use of computer technology can lead to productivity gains through improved communication possibilities among employees.

Three main channels can be observed when university teaching is reorganized to adjust for the new possibilities of ICT. First, the student-centred model of learning implies that students are more involved in all the tasks 
of learning. They are spending more time on learning (autonomous, more involved) and they are claiming more courses related to ICT. The second channel is related to the diversity of learning mechanisms. While learningby-studying is the most used form in the classical way of learning, the use of ICT allows more learning mechanisms to be used, namely learning-by-doing, learning-before-doing, learning-by-using, learning-from-competitors (other students). This diversity of the forms of learning is due to changes in the organization of courses and the organization of the whole study program. The third and last channel is related to collaborative learning. ICT are also collaborative technologies and enable better students' collaboration at the universities. For this purpose, organizational changes are needed that allow for more "cooperation" and "collaboration" between students themselves and between students and teachers.

(1) Students' behavioural change: autonomy, problem solving and involvement

ICT use at universities enables them to switch from a teacher-centred pedagogy to a learner-centred one (Keengwe et al., 2009; Saulnier et al., 2008). This requires an educational organization that is based on an active way of learning with different activities, which are determined by learners in small groups and where pace is determined by learners individually. By contrast, in the classical way of teaching, there is little variation in activities, they are prescribed by the teacher in a whole class instruction, and pace is determined by the program. (Barak et al., 2006) state that engagement of students in active learning and problem solving through ICT is a key to pedagogically successful use of ICT.

More involvement of students by using these tools and improving ICT uses are a first step toward a better performance in terms of e-skills. Different learning strategies ought to be implemented in order to increase the autonomy and the involvement of the student in classroom interactions. A large part of the learning process becomes centred on interactions outside the classroom where the involvement of the student is central. These changes can be observed through the change of the students' behaviour relating to the time spent on the Internet for pedagogical purposes and of the enrolment in more courses related to ICT (Ebner et al., 2010; Sivapalan and Cregan, 2005).

These organizational changes are also observed in firms. These need more autonomous workers, with the ability to take initiatives and to be fully involved in their job. Part of their job is done outside the firm's premises and the workers' capabilities developed during their higher education can be used for their jobs. To summarize, the organizational changes within univer- 
sities foster e-skill acquisition and prepare prospective workers for the NOP in firms (Blass, 2005; Fernandez, 2007). These changes tend to improve their employability and increase their future wages.

(2) Diversity of learning mechanisms instead of static learning: innovativeness, and technological absorptive capacity

"ICT has been transforming the way we communicate, the way we do business, the way we work, it is inevitable that it changes the way we learn" (Zammit, 2004). According to Zammit, 2004, the learning process is changing. In the presence of ICT more mechanisms of learning are available, from which students can choose. According to the classification by Pavitt, 1985 there are at least five kind of learning processes: learning-byusing, learning-by-doing, learning-from-competitors, learning-by-failing, and learning-by-studying. Universities are seeking to diversify the mechanisms of learning through the use of ICT. Many have implemented an organizational change in the organization of learning processes by developing more interactions between students and teachers and between students themselves.

The fact that students are exploring more mechanisms of learning may help them to develop their skills for more technological absorptive capacity. These skills are at the heart of the new organizational model of the firm today (Caroli, 2001). Firms are seeking workers who are able to learn and develop the capability to absorb new technologies and new knowledge and it appears to be important that during their higher education students develop these competencies.

(3) Collaborative and cooperative learning: Modularity, team work, work by project

ICT facilitates educational collaborations between individuals and groups of people. Such collaborations may take place locally or between people in separate geographical locations. Students may collaborate with peers in other schools, teachers may collaborate with their peers, members of the local business community may serve as mentors to students, and so forth. According to (Thijs et al., 2001), there is a move from a traditional pedagogic organization to an emerging pedagogic organization (in the information society) based on an active, collaborative (working in teams within heterogeneous groups where students support each other rather than individual work in heterogeneous groups where everyone works for himself/herself), creative (productive learning rather than reproductive learning), integrative (between theory and practice and between different subjects and disciplines) and evaluative learning (towards a more diagnostic approach rather than summative and student directed rather than teacher-directed). ICT and organizational 
change within the university are complementary as they jointly allow more cooperative and collaborative learning.

The last decade has seen major changes in French universities ${ }^{3}$. Firstly, universities became more autonomous ${ }^{4}$. They are in control of their own resources, setting their own strategies, and managing their own human resources. This major change implies that there is a change from a central hierarchical model of the university to a more dynamic and decentralised model where competition between universities is becoming the rule. Universities then more autonomously chose their pedagogical strategies. Secondly, French universities are trying to consider pedagogy as one of the three components for evaluating their teachers $/$ researchers $^{5}$. The two other components are publications success and involvement in the institution by taking on some responsibilities. This has led some teachers to explore new pedagogical strategies. Thirdly, several initiatives were taken in order to reverse the tendency of high student dropout rates in the initial years at university. These initiatives have tried to use ICT, online tutoring, collaborative work, and work in small groups in order to improve the success and retention rate in initial years at university. These initiatives have tried to change the way courses are organized. Fourthly, several universities (especially in the fields of economics and management) have invested in the content production of elearning programs. This strategy involved teachers, staff and students. Most French universities are currently trying to offer blended learning and to use some of the resources developed online for regular students attending class.

The fact that students are trained to be cooperative and collaborative is likely to give them better prospects of successfully integrating in teams and working by projects. These abilities are also important requirements in the professional world and, thus, critical success factors in the labour market. Improving these kinds of skills in higher education can thus be seen as important investments for the labour market. As alluded to above, these NOP are widely used within the firms nowadays. Several contributions have shown that the complementarities between the adoption of organizational change

\footnotetext{
${ }^{3}$ Many other changes have occurred and were not taken into account in our article. They have also contributed to the redesigning of the organization of courses within French universities.

${ }^{4}$ The new organization of French Universities is organized within the new law $n^{\circ} 2007$ $1199(08 / 10 / 2007)$. According to this law universities are able to set their own policies without interference by the Ministry of Higher Education.

${ }^{5}$ Initially the evaluation was based upon publication. Higher Education Teachers were not « incited » to invest in pedagogy. Most of them have not followed any pedagogical training (Ben Youssef and Hadhri, 2009).
} 
and adoption of ICT lead to better productivity of firms' performances. By acquiring these competencies students are better skilled and have greater probability of having a job (Hakkarainen et al., 2000).

\section{Data and methodology}

This section presents the data used in this study. We elaborate on the sources of the dataset, their limitations, and how the data was collected. Finally, we provide some descriptive statistics of the variables used in this study.

\subsection{Data collection}

The data were collected by a survey conducted in France in 2010. The survey investigates the adoption and use of ICT by students. We used the survey approach, instrumented via a face-to-face questionnaire data-gathering technique. The questionnaire includes four parts: the first concerns the characteristics of the student, the second explores the motivation of the student for study, the third seeks to assess the facilitating conditions, while the fourth seeks to account the diversity of ICT uses which students use.

A pilot study with a group of 20 students was undertaken in order to ensure the questions were adapted appropriately to the research context. The purpose was to find out potential problems and misunderstandings of instruction and question items. After the pilot test, some small adjustments were made. Finally, a total of 1522 students took part in the survey. In order to accomplish the research objectives and the econometric analysis of the data, it was necessary to exclude respondents that reported inconsistent responses and respondents who did not answer all the questions. After these adjustments the sample consists of 1464 observations.

\subsection{Sample characteristics}

The final sample contains 1464 students in the field of economics and management from three French universities: University of Paris Ouest - Nanterre la Défense, University of Paris-Sud and University of Nice Sophia-Antipolis. The descriptive statistics are summarized in Table 1. Of the surveyed students, $69.4 \%$ belong to the University of Paris-Sud 11, $21.2 \%$ to the University of Nice Sophia-Antipolis and $9.4 \%$ to the University of Paris-Ouest Nanterre La Défense. Around $40 \%$ of respondents were carrying out their first year of undergraduate degree studies, $36 \%$ their second year of undergraduate degree and $24 \%$ their third and final year of the undergraduate degree. More than $31 \%$ of the sample carried out professional activities in parallel with their studies. In our sample, $52.2 \%$ of all students are male and $47.8 \%$ female. 
Respondents' ages are divided into various age groups. The age mean of our sample is 21 . The average age of female students is 20 while it is 21 for male.

A majority of respondents $(78 \%)$ reported that their institution has developed ICT student training programmes for them. Around $68 \%$ of respondents state that their university provides ICT training. Around $58 \%$ of respondents claim to have followed an ICT tools use training. Only around $36 \%$ of respondents reported that they had attended an ICT training programme inside or outside their institution with the aim to use ICT effectively for learning purposes. Almost $89 \%$ of respondents have a computer at home. Similarly, the vast majority of respondents (80.5\%) have a laptop. And almost all students have an Internet connection at home (96.2\%). Most of the respondents spend between 1 and 5 hours per week using Internet for educational purpose, $20.1 \%$ use it for less than an hour per week, $14.8 \%$ between 6 and 9 hours, $5.3 \%$ from 10 to 14 hours and only $3.9 \%$ use it for more than 15 hours. Table 1 reports these sample statistics. 
Table 1: Sample description

\begin{tabular}{|c|c|c|c|}
\hline Variables $(\mathrm{N}=1464)$ & Distribution (\%) & Min & Max \\
\hline \multicolumn{4}{|l|}{ Gender } \\
\hline Female & 47.7 & 0 & 1 \\
\hline Male & 52.3 & 0 & 1 \\
\hline \multicolumn{4}{|l|}{ Age } \\
\hline 17 to 19 & 39.3 & 0 & 1 \\
\hline 20 to 21 & 36.7 & 0 & 1 \\
\hline 22 to 23 & 20.8 & 0 & 1 \\
\hline 24 and more & 3.1 & 0 & 1 \\
\hline \multicolumn{4}{|l|}{ University } \\
\hline University of Paris-Sud & 69.3 & 0 & 1 \\
\hline University of Nice-Sophia Antipolis & 21.2 & 0 & 1 \\
\hline University of Paris 10 & 9.5 & 0 & 1 \\
\hline \multicolumn{4}{|l|}{ Level of education } \\
\hline First year of undergraduate degree & 40.0 & 0 & 1 \\
\hline Second year of undergraduate degree & 36.1 & 0 & 1 \\
\hline Third and final year of undergraduate degree & 23.8 & 0 & 1 \\
\hline \multicolumn{4}{|l|}{ Having a job while studying } \\
\hline Not having a job while studying & 67.0 & 0 & 1 \\
\hline Having a job while studying & 33.0 & 0 & 1 \\
\hline \multicolumn{4}{|l|}{ Computer at home } \\
\hline Not having a computer at home & 11.1 & 0 & 1 \\
\hline Having a computer at home & 88.9 & 0 & 1 \\
\hline \multicolumn{4}{|l|}{ Laptop } \\
\hline Not having a laptop & 19.5 & 0 & 1 \\
\hline Having a laptop & 80.5 & 0 & 1 \\
\hline \multicolumn{4}{|l|}{ Internet connection at home } \\
\hline Not having an Internet connection at home & 3.8 & 0 & 1 \\
\hline Having an Internet connection at home & 96.2 & 0 & 1 \\
\hline \multicolumn{4}{|l|}{ Provision ICT training by the university } \\
\hline The university did not provide ICT training & 32.0 & 0 & 1 \\
\hline The university provided ICT training & 68.0 & 0 & 1 \\
\hline \multicolumn{4}{|l|}{ Following an ICT use training } \\
\hline Not following an ICT use training & 58.3 & 0 & 1 \\
\hline Following an ICT use training & 41.7 & 0 & 1 \\
\hline \multicolumn{4}{|c|}{ Time spent on the Internet for educational purposes } \\
\hline Less than one hour per week & 20.1 & 0 & 1 \\
\hline 1 to 5 hours & 55.9 & 0 & 1 \\
\hline 6 to 9 hours & 14.8 & 0 & 1 \\
\hline 10 to 14 hours & 5.3 & 0 & 1 \\
\hline 15 hours and more & 3.9 & 0 & 1 \\
\hline
\end{tabular}




\subsection{Econometric model}

The objective of this study is to identify the determinants of students' e-skills. We assume that the probability that a student is in one of the four different categories of e-skills depends on his/her characteristics, involvement to the use of ICT, the level of ICT use, and the use of ICT tools for collaborative and cooperative purpose. Under this assumption of a discrete choice, the appropriate model is a multinomial $\operatorname{logit}^{6}$, shown in equation (1) below. This model determines if the relevant factors identified in the literature review (presented above) are related to the probability of students to be in one of the four different e-skills categories. Let ESKILLS denote the $i^{\text {th }}$ student's category of e-skills variable, which can then be observed as:

$$
\text { ESKILLS }=\left\{\begin{array}{l}
=1 \text { if the student } i \text { has operational e-skills } \\
=2 \text { if the student } i \text { has formal e-skills } \\
=3 \text { if the student } i \text { has information e-skills } \\
=4 \text { if the student } i \text { has strategic e-skills }
\end{array}\right.
$$

The multinomial logit model is then defined by the following equation ${ }^{7}$.

$$
\operatorname{Prob}\left(\text { ESKILLS }=m \mid X_{i}\right)=\frac{\exp \left(\beta_{m}^{\prime} X_{i}\right)}{\sum_{j=1}^{4} \exp \left(\beta_{j}^{\prime} X_{i}\right)}
$$

Where $m=1,2,3$ or 4 and $j=1, \ldots, m$, ESKILLS denotes the observed outcome, $\beta$ denotes a vector of coefficients, $X$ is a vector consisting of ICT skills variables and other explanatory variables such as age, gender, university, level of education, other related ICT facilities, etc. The coefficients are then estimated by maximum likelihood.

When estimating a multinomial logit model it is required to choose a reference category with coefficients normalized to $0^{8}$. Due to the requirement of a reference group, the coefficients from other groups should be compared to this reference group. The reference group is then defined by the following equation.

\footnotetext{
${ }^{6}$ Please note that we also tested our adoption equation through ordered logit and ordered probit models. The results achieved were very similar, which confirms the robustness of the equation. Nevertheless, the multinomial logit model was preferred insofar as it is difficult to interpret the ESKILLS_3 and ESKILLS_ 4 classes as ordered in terms of categories of e-skills.

${ }^{7}$ See e.g. Maddala (1993) or Franses and Paap (2001).

${ }^{8}$ In this study the reference category is 1 , i.e. operational e-skills.
} 


$$
\operatorname{Prob}\left(\mathrm{ESKILLS}=0 \mid X_{i}\right)=\frac{1}{\sum_{j=1}^{4} \exp \left(\beta_{j}^{\prime} X_{i}\right)}
$$

\subsection{Variables}

This section presents the variables used in the econometric analysis. Two sets of variables are defined, dependent variable, namely, e-skills level and independent variables, namely determinants of students' e-skills accumulation. The first set of variables is obtained through a classification procedure. They identify and characterize the different levels of students' e-skills. The second set of variables contains the explanatory variables related to the characteristics of the students, their involvement to the use of ICT, the level of their ICT use, and the use of ICT tools for collaborative and cooperative purpose.

\subsubsection{Dependent variable: Students' e-skills}

The participants in our survey were asked to rate their level of skills and the frequency with which they use nineteen ICT applications. These ICT variables are specified through five-point Likert scale responses, ranging from value "1" for students who have neither adopted, nor tested these technologies to value " 5 " for the earliest adopters and those who use them intensively.

To characterize the different modes of ICT usages and skills, a Principal Component Analysis (PCA) was conducted with the nineteen variables. The PCA resulted in four factors with an eigenvalue larger than 1 (see Table 2). The total variance explained by these factors is $53.33 \%$. Generally in social sciences this rate is considered as satisfactory (Hair et al., 2006). We defined the factors as following:

- Factor 1: The generic use of computer

- Factor 2: The generic use of Internet

- Factor 3: The use of ICT for pedagogic purposes

- Factor 4: The use of ICT for collaborative work purposes

In order to test the reliability of the summated scale, the internal consistency reliability was verified by Cronbach's alpha. The coefficient varies from 0 to 1 , and a value of 0.6 or less generally indicates unsatisfactory internal consistency reliability (Malhotra, 2009). In social sciences, acceptable reliability estimates range from 0.7 to 0.8 (Nunnally and Bernstein, 1994). The results (documented in Table 3) reveal that the Cronbach's alpha values 
Table 2: Results of the Principal Component Analysis for the different modes of ICT usages and skills

\begin{tabular}{|l|c|c|c|c|}
\hline \multirow{2}{*}{} & \multicolumn{4}{|c|}{ Factor } \\
\cline { 2 - 5 } & F1 & F2 & F3 & F4 \\
\hline \hline Proficiency in presentation software & 0.821 & & & \\
\hline Proficiency in word processing software & 0.802 & & & \\
\hline Proficiency in spreadsheet software & 0.786 & & & \\
\hline Proficiency in discipline-specific software & 0.559 & & & \\
\hline Proficiency in device installation & 0.528 & & & \\
\hline Proficiency in social networks applications & & 0.769 & & \\
\hline Proficiency in forum and chat applications & & 0.731 & & \\
\hline Proficiency in messaging software & & 0.656 & & \\
\hline Proficiency in search engine & & 0.528 & & \\
\hline Encyclopaedias use as support of courses & & & 0.735 & \\
\hline Databases use as support of course & & & 0.706 & \\
\hline Forums use as support of course & & & & 0.563 \\
\hline Team work using ICT & & & & 0.806 \\
\hline Internet use as a tool for setting goals & & & & 0.736 \\
\hline Technology use to facilitate working with colleagues & & & & 0.717 \\
\hline Task work using Internet & & & & 0.635 \\
\hline Parallel work on multiple projects using ICT & & & & \\
\hline Internet use for research projects & & & \\
\hline Internet use to facilitate information flow & & & & \\
\hline
\end{tabular}

Notes: Extraction Method: Principal Component Analysis.

Rotation Method: Varimax with Kaiser Normalization.

Rotation converged in 5 iterations.

for each of the four dimensions were greater than 0.7 except for generic use of Internet dimension (0.67).

The Bartlett's Test of Sphericity shows that non-zero correlations exist at the significance level of $1 \%$. The reduced set of variables meets the necessary threshold with a Kaiser-Meyer-Olkin measure of sampling adequacy value of 0.86. All of these findings provide evidence of the appropriateness of the sample for the principal components analysis.

In order to identify the different levels of students' e-skills, we group the 1464 students using cluster analysis. Cluster analysis was conducted using Stata (version 11) software in order to explore options for grouping the different students' e-skills levels. The objective of cluster analysis is to find homogeneous groups and to maximize the differences between groups. Unlike most parametric statistical techniques, cluster analysis does not explicitly provide a clearly acceptable or unacceptable solution. Bocquet and Brossard, 2007 and Sharma, 1995 recommend that one should use different approaches, 
Table 3: Reliability and goodness of fit of factors statistics for students' e-skills PCA

\begin{tabular}{|l|c|c|c|c|}
\hline Factor & Eigenvalue & $\begin{array}{c}\text { Percent } \\
\text { of } \\
\text { variance }\end{array}$ & $\begin{array}{c}\text { Cumulative } \\
\text { percent of } \\
\text { variance }\end{array}$ & $\begin{array}{c}\text { Cronbach's } \\
\text { alpha }\end{array}$ \\
\hline \hline F1: The generic use of computer & 4.919 & 25.89 & 25.89 & 0.77 \\
\hline F2: The generic use of Internet & 2.57 & 13.528 & 39.418 & 0.67 \\
\hline F3: The use of ICT for pedagogic purposes & 1.361 & 7.161 & 46.579 & 0.74 \\
\hline F4: The use of ICT for collaborative work purposes & 1.284 & 6.759 & 53.339 & 0.85 \\
\hline \multicolumn{2}{|c|}{ KMO and Bartlett's Test } \\
\hline Kaiser-Meyer-Olkin Measure of Sampling Adequacy. \\
\hline Bartlett's Test of Sphericity & \multicolumn{3}{|c|}{ Approx. Chi-Square } & \multicolumn{2}{|c|}{8169.35} \\
\hline \multicolumn{2}{|r|}{ Sig. } \\
\hline
\end{tabular}

compare the results for consistency and use the method that results in an interpretable solution.

A non-hierarchical cluster analysis (ESKILLS) based on $k$-means methodology is then carried out based on the scores revealed by the principal factor analysis. In order to determine the final number of clusters, we use three usual criteria:

- the statistical accuracy of the classification measured by the ratio of within;

- cluster and between-clusters variances (Fisher's test);

- the number of teachers per cluster, - the economic significance of the clusters identified.

According to these criteria, the version with four clusters of e-skills is adopted. In order to interpret these four clusters, we calculate the mean of each ICT indicator ("generic use of computer", "generic use of Internet", "use of ICT for pedagogic purposes" and "use of ICT for collaborative work purposes") in each cluster.

The levels of student e-skills of the four clusters (profiles) are illustrated in Table 4 and can be interpreted as following:

Profile 1: Operational e-skills (ESKILLS_1). This group includes $25.96 \%$ of students (380 students) who are the later adopters of the ICT and do not use them intensively. They typically have text processing skills and have used some aspects of presentation and spreadsheets software. Generally, students from Profile 1 have not used specialized software or collaborative applications. They especially have the basic skills to operate the computer.

Profile 2: Formal e-skills (ESKILLS_2). This group includes $32.51 \%$ of students (476 students) who in addition to possessing the op- 
Table 4: Interpretation of ESKILLS clusters

\begin{tabular}{|c|c|c|c|c|}
\hline \multirow{2}{*}{ ESKILLS } & \multicolumn{4}{|c|}{ Mean } \\
\hline & GENCOMP & GENINT & ICTPED & ICTCOLL \\
\hline No. $1=$ Operational e-skills (ESKILLS_1) $(\mathrm{N}=380)$ & 2.56 & 2.31 & 2.06 & 2.41 \\
\hline No. $2=$ Formal e-skills (ESKILLS_2) $(\mathrm{N}=476)$ & 3.06 & 3.56 & 2.22 & 2.96 \\
\hline No. $3=$ Information e-skills (ESKILLS_3) $(\mathrm{N}=356)$ & 2.99 & 3.14 & 3.37 & 3.70 \\
\hline No. $4=$ Strategic e-skills (ESKILLS_4) $(\mathrm{N}=252)$ & 3.93 & 4.50 & 3.12 & 3.91 \\
\hline \multicolumn{5}{|c|}{ Notes: The mean is in bold value when it is significantly higher in the considered cluster. } \\
\hline \multicolumn{5}{|c|}{ GENCOMP: Generic use of computer } \\
\hline \multicolumn{5}{|l|}{ GENINT: Generic use of Internet } \\
\hline \multicolumn{5}{|l|}{ ICTPED: Use of ICT for pedagogic purposes } \\
\hline ICTCOLL: Use of ICT for collaborativ & & & & \\
\hline
\end{tabular}

erational skills listed in Profile 1, declared to use Internet applications like search engine, network application and messaging software. Students from Profile 2 tend to have some information skills.

Profile 3: Information e-skills (ESKILLS_3). This group (356 students; $24.32 \%$ ) is represented by students who are not proficient in ICT but have sophisticated learning mechanisms are willing to learn new ICT tools to reconstruct their learning practices. This group is also strong on operational and formal skills.

Profile 4: Strategic e-skills (ESKILLS_4). Students belonging to this group (252 students; $17.21 \%$ ) are earlier adopters and use ICT intensively. They are characterized by high e-skills. In addition, the use of collaborative applications is widespread in this cluster indicating that especially students who have expertise in and access to these ICT tools are using ICT to support collaborative learning.

The four dummy variables ESKILLS_1, ESKILLS_2, ESKILLS_3 and ESKILLS_4 used in the econometric analysis below result from this procedure. They represent the four identified modes of ICT usages.

\subsubsection{Independent variables}

Students' characteristics: Gender, students' age, level of education, home university and having job while studying can be expected to influence student's e-skills levels.

ICT access: ICT access is measured by different items, which relate to both ICT equipment such as the possession of a laptop or a computer at home, having domestic Internet connection and ICT help and support such as the availability of discipline-specific software, the availability of help and support and ICT training provided by the university. The variables where coded as a "1" if the respondent answered with a "yes $(=1)$ ", otherwise a "no $(=0)$ ".

Students' involvement: Students' involvement reflects the students' 
effort in order to use ICT efficiently. This variable is measured by two items, which are first, students' ICT training, coded as a "1" if the respondent answered with a "yes $(=1)$ ", otherwise a "no $(=0)$ ". Second, students were also asked about the use of Internet for pedagogical purposes. They ranked the extent of their usage on a scale of five points (1-5) specifically, less than one hour per week (1), from 1 to 5 hours (2), from 6 to 9 hours (3), from 10 to 14 hours (4), and more than 15 hours (5).

Learning mechanisms: Two sets of variables were used to measure students' learning mechanisms: ICT learning by doing and ICT learning by using. In our survey we assume that a student accumulates ICT skills by doing if he/she tries out new applications, if he/she is an early tester of new computer applications or if he/she participates in applications development. Furthermore, two variables tap the ICT learning by using dimension. Two items assess mobile devices use: flexible versus fix scheduled work and use of mobile tools. The students were asked if working at any time during the day is more efficient than working at fixed time and whether they use mobile tools in order to prepare their homework. The responses are coded 1 if the respondent says "yes", 0 otherwise.

Collaborative and cooperative learning: In order to measure students' collaborative and cooperative learning, we use seven items. ICT use is seen as collaborative and cooperative learning tools when the student believes that Internet use enhances collaboration with other students, when he/she states that Internet use improves the work presentation and organization. This variable is also measured by the student's belief that Internet is useful to provide business creation ideas and innovative ideas, and that ICT is important for learning due to the fact that these tools give them the opportunity to contact the teacher or the tutor by e-mail. In addition, it measures the ability to communicate and to discuss a course issue online and the belief that Internet use enables them to obtain a deeper understanding of the content developed in class. Respondents were asked to indicate the extent of their agreement with each item on a five-point scale, ranging from 1-strongly disagree to 5 -strongly agree.

\section{Empirical results}

This section presents the empirical results of the determinants of students' e-skills in France. First, the goodness-of-fit tests for the model are presented. Second, the results from the estimated multinomial logit model and the marginal effects related to ESKILLS variable are presented and discussed. Finally, the results of the appropriateness of the model test are presented. The empirical results from the estimated multinomial logit model 
and the marginal effects are reported in tables 5 and 6 . The log-likelihood value for the model is -1440.6086 .

Table 5: Results from the multinomial logit model

\begin{tabular}{|c|c|c|c|}
\hline $\begin{array}{l}\text { Dependent variables } \\
\text { Operational e-skills }\end{array}$ & $\begin{array}{l}\text { Formal } \\
\text { e-skills }\end{array}$ & $\begin{array}{l}\text { Information } \\
\text { e-skills }\end{array}$ & $\begin{array}{l}\text { Strategic } \\
\text { e-skills }\end{array}$ \\
\hline \multicolumn{4}{|l|}{ Independent variables } \\
\hline \multicolumn{4}{|l|}{ Student characteristics } \\
\hline Gender & $0.03(0.167)$ & $-0.04(0.193)$ & $\begin{array}{l}0.56^{* *} \\
(0.249) \\
\end{array}$ \\
\hline \multicolumn{4}{|l|}{ University } \\
\hline University of Paris-Sud 11 & Ref. & Ref. & Ref. \\
\hline University of Nice-Sophia & $0.90^{* * *}$ & $-0.08(0.289)$ & $1.22^{* * *}$ \\
\hline Antipolis & $(0.237)$ & & $(0.337)$ \\
\hline University of Paris 10 & $0.28(0.299)$ & $-0.30(0.350)$ & $0.07(0.439)$ \\
\hline \multicolumn{4}{|l|}{ Level of education } \\
\hline $\begin{array}{l}\text { First year of } \\
\text { undergraduate degree }\end{array}$ & Ref. & Ref. & Ref. \\
\hline $\begin{array}{l}\text { Second year of } \\
\text { undergraduate degree }\end{array}$ & $0.11(0.217)$ & $-0.07(0.251)$ & $0.11(0.318)$ \\
\hline $\begin{array}{l}\text { Third and final year of } \\
\text { undergraduate degree }\end{array}$ & $0.10(0.253)$ & $0.32(0.285)$ & $0.64^{*}(0.373)$ \\
\hline \multicolumn{4}{|l|}{ Age } \\
\hline 17 to 19 & Ref. & Ref. & Ref. \\
\hline 20 to 21 & $0.05(0.214)$ & $0.18(0.247)$ & $0.31(0.309)$ \\
\hline 22 to 23 & $-0.22(0.258)$ & $-0.42(0.297)$ & $-0.48(0.388)$ \\
\hline 24 and older & $\begin{array}{l}-1.30^{* * *} \\
(0.474)\end{array}$ & $\begin{array}{l}-1.49 * * * \\
(0.531)\end{array}$ & $\begin{array}{l}-2.10 * * * \\
(0.780)\end{array}$ \\
\hline Having a job while studying & $0.24(0.178)$ & $\begin{array}{l}0.40^{* *} \\
(0.201)\end{array}$ & $\begin{array}{l}0.61^{* * *} \\
(0.249)\end{array}$ \\
\hline \multicolumn{4}{|l|}{ ICT access } \\
\hline Having a computer at home & $-0.13(0.242)$ & $0.12(0.293)$ & $\begin{array}{l}1.30^{* * *} \\
(0.485)\end{array}$ \\
\hline Having a laptop & $0.17(0.188)$ & $0.39 *(0.233)$ & $0.58 *(0.320)$ \\
\hline $\begin{array}{l}\text { Internet connection at } \\
\text { home }\end{array}$ & $0.42(0.386)$ & $0.10(0.497)$ & $\begin{array}{l}-1.27^{* *} \\
(0.649)\end{array}$ \\
\hline $\begin{array}{l}\text { Availability of } \\
\text { discipline-specific software }\end{array}$ & $0.04(0.070)$ & $\begin{array}{l}0.26^{* *} \\
(0.085)\end{array}$ & $\begin{array}{l}0.27^{* * *} \\
(0.113)\end{array}$ \\
\hline
\end{tabular}

Continued on next page... 


\begin{tabular}{|c|c|c|c|}
\hline Operational e-skills & $\begin{array}{l}\text { Formal } \\
\text { e-skills }\end{array}$ & $\begin{array}{l}\text { Information } \\
\text { e-skills }\end{array}$ & $\begin{array}{l}\text { Strategic } \\
\text { e-skills }\end{array}$ \\
\hline $\begin{array}{l}\text { Availability of help and } \\
\text { support }\end{array}$ & $0.01(0.069)$ & $0.11(0.079)$ & $\begin{array}{l}0.23^{* *} \\
(0.105)\end{array}$ \\
\hline $\begin{array}{l}\text { The university provides } \\
\text { ICT training }\end{array}$ & $\begin{array}{l}0.52^{* * *} \\
(0.169)\end{array}$ & $0.30(0.199)$ & $0.47^{*}(0.267)$ \\
\hline \multicolumn{4}{|l|}{ Students' involvement } \\
\hline Student ICT use training & $0.18(0.168)$ & $\begin{array}{l}0.50 * * * \\
(0.190)\end{array}$ & $0.43^{*}(0.240)$ \\
\hline \multicolumn{4}{|c|}{ Hours spent per week surfing for pedagogical purposes } \\
\hline Less than one hour & Ref. & Ref. & Ref. \\
\hline 1 to 5 hours & $0.05(0.191)$ & $0.41^{*}(0.247)$ & $-0.30(0.323)$ \\
\hline 6 to 9 hours & $0.42(0.293)$ & $\begin{array}{l}1.01^{* * *} \\
(0.341)\end{array}$ & $0.06(0.426)$ \\
\hline 10 to 14 hours & $0.34(0.489)$ & $\begin{array}{l}1.15^{* *} \\
(0.520) \\
\end{array}$ & $\begin{array}{l}1.55^{* * *} \\
(0.580) \\
\end{array}$ \\
\hline 15 hours and more & $-0.33(0.685)$ & $0.62(0.696)$ & $\begin{array}{l}1.76^{* * *} \\
(0.716)\end{array}$ \\
\hline \multicolumn{4}{|l|}{ Learning mechanisms } \\
\hline \multicolumn{4}{|l|}{ Learning by doing } \\
\hline To test new applications & $0.18(0.111)$ & $\begin{array}{l}0.25^{* *} \\
(0.130) \\
\end{array}$ & $\begin{array}{l}0.63^{* * *} \\
(0.158)\end{array}$ \\
\hline $\begin{array}{l}\text { Primary tester of new } \\
\text { computer applications }\end{array}$ & $\begin{array}{l}0.43^{* * *} \\
(0.107)\end{array}$ & $\begin{array}{l}0.40 * * * \\
(0.123)\end{array}$ & $\begin{array}{l}0.38^{* * *} \\
(0.146)\end{array}$ \\
\hline Applications development & $\begin{array}{l}0.25^{* * *} \\
(0.085)\end{array}$ & $\begin{array}{l}0.37^{* * *} \\
(0.093)\end{array}$ & $\begin{array}{l}0.44^{* * *} \\
(0.106)\end{array}$ \\
\hline \multicolumn{4}{|l|}{ Learning by using } \\
\hline $\begin{array}{l}\text { Flexible versus fixed } \\
\text { schedule }\end{array}$ & $0.10(0.067)$ & $\begin{array}{l}0.18^{* *} \\
(0.077)\end{array}$ & $\begin{array}{l}0.26^{* * *} \\
(0.099)\end{array}$ \\
\hline Use of mobile tools & $0.08(0.063)$ & $\begin{array}{l}0.21^{* * *} \\
(0.071) \\
\end{array}$ & $\begin{array}{l}0.41^{* * *} \\
(0.091) \\
\end{array}$ \\
\hline \multicolumn{4}{|c|}{ Collaborative and cooperative learning } \\
\hline $\begin{array}{l}\text { Internet use enhances } \\
\text { collaboration with other } \\
\text { students }\end{array}$ & $\begin{array}{l}0.25^{* * *} \\
(0.077)\end{array}$ & $\begin{array}{l}0.35^{* * *} \\
(0.092)\end{array}$ & $\begin{array}{l}0.52^{* * *} \\
(0.122)\end{array}$ \\
\hline $\begin{array}{l}\text { Internet use improves the } \\
\text { work presentation and } \\
\text { organization }\end{array}$ & $-0.04(0.081)$ & $0.16^{*}(0.096)$ & $\begin{array}{l}0.52^{* * *} \\
(0.132)\end{array}$ \\
\hline
\end{tabular}

Continued on next page... 


\begin{tabular}{|c|c|c|c|}
\hline Operational e-skills & $\begin{array}{l}\text { Formal } \\
\text { e-skills }\end{array}$ & $\begin{array}{l}\text { Information } \\
\text { e-skills }\end{array}$ & $\begin{array}{l}\text { Strategic } \\
\text { e-skills }\end{array}$ \\
\hline $\begin{array}{l}\text { Internet provides business } \\
\text { creation ideas }\end{array}$ & $0.14(0.089)$ & $0.12(0.099)$ & $\begin{array}{l}0.55^{* * *} \\
(0.122)\end{array}$ \\
\hline $\begin{array}{l}\text { Internet provides innovative } \\
\text { ideas }\end{array}$ & $0.09(0.090)$ & $\begin{array}{l}0.22 * * \\
(0.102)\end{array}$ & $\begin{array}{l}0.25 * * \\
(0.135)\end{array}$ \\
\hline $\begin{array}{l}\text { Having the opportunity to } \\
\text { contact the teacher / tutor } \\
\text { by e-mail }\end{array}$ & $\begin{array}{l}0.28^{* * *} \\
(0.078)\end{array}$ & $\begin{array}{l}0.39 * * * \\
(0.096)\end{array}$ & $\begin{array}{l}0.35^{* * *} \\
(0.132)\end{array}$ \\
\hline $\begin{array}{l}\text { Being able to communicate } \\
\text { and discuss a course issues } \\
\text { online }\end{array}$ & $-0.09(0.076)$ & $\begin{array}{l}0.22^{* * *} \\
(0.088)\end{array}$ & $\begin{array}{l}0.35^{* * *} \\
(0.117)\end{array}$ \\
\hline $\begin{array}{l}\text { Internet use enables } \\
\text { student to deepen the } \\
\text { content developed in class }\end{array}$ & $\begin{array}{l}0.17^{* *} \\
(0.077)\end{array}$ & $\begin{array}{l}0.32^{* * *} \\
(0.092)\end{array}$ & $\begin{array}{l}0.44^{* * *} \\
(0.124)\end{array}$ \\
\hline Pseudo $R^{2}$ & 27.76 & & \\
\hline Log likelihood & -1440.6086 & & \\
\hline $\operatorname{LR}(96)$ & $1106.97^{* * *}$ & & \\
\hline
\end{tabular}

Note: The notation ${ }^{* * *},{ }^{* *}$, and ${ }^{*}$ denotes significance at the $1 \%, 5 \%$ and $10 \%$.

The likelihood ratio $\left(\chi^{2}\right)$ value of 1106.97 is greater than the critical chisquare value $\left(\chi_{0.001}^{2}, 96\right)$ of 137.208 , and $\left(\chi_{0.01}^{2}, 96\right)$ of 131.14 at the $0.1 \%$ and $1 \%$ levels of significance. This test confirms that all the slope coefficients are significantly different from zero. The alternative hypothesis is thus accepted at these levels of significance.

Table 6: Marginal effects of the multinomial logit model

\begin{tabular}{|c|c|c|c|c|c|c|}
\hline \multirow{2}{*}{$\begin{array}{l}\text { Dependent variables } \\
\text { Operational e-skills }\end{array}$} & \multicolumn{2}{|c|}{ Formal e-skills } & \multicolumn{2}{|c|}{ Information e-skills } & \multicolumn{2}{|c|}{ Strategic e-skills } \\
\hline & $\operatorname{Exp}(\beta)$ & $\begin{array}{l}\text { Margina } \\
\text { Effects }\end{array}$ & $\operatorname{Exp}(\beta)$ & $\begin{array}{l}\text { Marginal } \\
\text { Effects }\end{array}$ & $\operatorname{Exp}(\beta)$ & $\begin{array}{l}\text { Marginal } \\
\text { Effects }\end{array}$ \\
\hline \multicolumn{7}{|l|}{ Independent variables } \\
\hline \multicolumn{7}{|c|}{ Student characteristics } \\
\hline Gender & 1.03 & 0.005 & 0.96 & -0.024 & $1.74^{* *}$ & $0.035^{* * *}$ \\
\hline \multicolumn{7}{|l|}{ University } \\
\hline $\begin{array}{l}\text { Université Paris-Sud } \\
11\end{array}$ & Ref. & - & Ref. & - & Ref. & - \\
\hline $\begin{array}{l}\text { UniversitéNice-Sophia } \\
\text { Antipolis }\end{array}$ & $2.45^{* * *}$ & $0.179 * * *$ & 0.92 & -0.156 & $3.38^{* * *}$ & $0.057^{* * *}$ \\
\hline
\end{tabular}

Continued on next page... 


\begin{tabular}{|c|c|c|c|c|c|c|}
\hline Operational e-skills & $\operatorname{Exp}(\beta)$ & $\begin{array}{l}\text { Margina } \\
\text { Effects }\end{array}$ & $\operatorname{Exp}(\beta)$ & $\begin{array}{l}\text { Marginal } \\
\text { Effects }\end{array}$ & $\operatorname{Exp}(\beta)$ & $\begin{array}{l}\text { Marginal } \\
\text { Effects }\end{array}$ \\
\hline Université Paris 10 & 1.32 & 0.107 & 0.74 & -0.096 & 1.07 & 0.001 \\
\hline \multicolumn{7}{|l|}{ Level of education } \\
\hline $\begin{array}{l}\text { First year of } \\
\text { undergraduate degree }\end{array}$ & Ref. & - & Ref. & - & Ref. & - \\
\hline $\begin{array}{l}\text { Second year of } \\
\text { undergraduate degree }\end{array}$ & 1.12 & 0.034 & 0.93 & -0.032 & 1.12 & 0.005 \\
\hline $\begin{array}{l}\text { Third and final year } \\
\text { of undergraduate } \\
\text { degree }\end{array}$ & 1.11 & 0.040 & 1.38 & 0.039 & $1.90^{*}$ & 0.055 \\
\hline \multicolumn{7}{|l|}{ Age } \\
\hline 17 to 19 years & Ref. & - & Ref. & - & Ref. & - \\
\hline 20 to 21 years & 1.06 & -0.021 & 1.20 & 0.024 & 1.36 & 0.015 \\
\hline 22 to 23 years & 0.81 & 0.015 & 0.66 & -0.048 & 0.62 & -0.015 \\
\hline 24 years and older & $0.27^{* * *}$ & -0.120 & $0.23^{* * *}$ & $-0.120^{*}$ & $0.12^{* * *}$ & $\begin{array}{l}- \\
0.047^{* * *}\end{array}$ \\
\hline $\begin{array}{l}\text { Having a job during } \\
\text { studies }\end{array}$ & 1.27 & 0.015 & $1.49^{* *}$ & 0.038 & $1.84^{* * *}$ & $0.067^{* *}$ \\
\hline \multicolumn{7}{|l|}{ ICT access } \\
\hline $\begin{array}{l}\text { Having a computer at } \\
\text { home }\end{array}$ & 0.88 & -0.076 & 1.13 & 0.025 & $3.69^{* * *}$ & $0.056^{* * *}$ \\
\hline Having a laptop & 1.19 & 0.026 & $1.48^{*}$ & 0.047 & $1.78^{*}$ & 0.077 \\
\hline $\begin{array}{l}\text { Internet connection at } \\
\text { home }\end{array}$ & 1.52 & 0.150 & 1.11 & 0.024 & $0.28^{* *}$ & $-0.171^{*}$ \\
\hline $\begin{array}{l}\text { Availability of } \\
\text { discipline-specific } \\
\text { software }\end{array}$ & 1.04 & -0.033 & $1.30^{* * *}$ & $0.044^{* * *}$ & $1.31^{* * *}$ & $0.010^{*}$ \\
\hline $\begin{array}{l}\text { Availability of help and } \\
\text { support }\end{array}$ & 1.00 & -0.021 & 1.11 & 0.017 & $1.26^{* *}$ & $0.012^{* *}$ \\
\hline $\begin{array}{l}\text { The university provides } \\
\text { ICT training }\end{array}$ & $1.68^{* * *}$ & $0.074^{* *}$ & 1.35 & 0.015 & $1.61^{*}$ & 0.052 \\
\hline \multicolumn{7}{|c|}{ Students' involvement } \\
\hline $\begin{array}{l}\text { Training in the use } \\
\text { of ICT }\end{array}$ & 1.19 & 0.039 & $1.65^{* * *}$ & $0.073^{* * *}$ & $1.53^{*}$ & 0.051 \\
\hline \multicolumn{7}{|c|}{ Hours spent per week surfing for pedagogical purposes } \\
\hline Less than one hour & Ref. & - & Ref. & - & Ref. & - \\
\hline 1 to 5 hours & 1.06 & 0.032 & $1.10^{*}$ & $0.084^{* *}$ & 0.74 & -0.030 \\
\hline 6 to 9 hours & 1.53 & 0.054 & $2.73^{* * *}$ & $0.163^{* * *}$ & 1.06 & 0.028 \\
\hline
\end{tabular}

Continued on next page... 


\begin{tabular}{|c|c|c|c|c|c|c|}
\hline Operational e-skills & $\operatorname{Exp}(\beta)$ & $\begin{array}{l}\text { Margina } \\
\text { Effects }\end{array}$ & $\operatorname{Exp}(\beta)$ & $\begin{array}{l}\text { Marginal } \\
\text { Effects }\end{array}$ & $\operatorname{Exp}(\beta)$ & $\begin{array}{l}\text { Marginal } \\
\text { Effects }\end{array}$ \\
\hline 10 to 14 hours & 1.41 & 0.146 & $3.16^{* *}$ & $0.157^{* *}$ & $4.71^{* * *}$ & $0.083^{*}$ \\
\hline 15 hours and more & 0.72 & -0.229 & 1.86 & 0.087 & $5.82^{* * *}$ & $0.196^{* *}$ \\
\hline \multicolumn{7}{|c|}{ Learning mechanisms } \\
\hline \multicolumn{7}{|l|}{ Learning by doing } \\
\hline $\begin{array}{l}\text { Test of new } \\
\text { applications }\end{array}$ & 1.19 & -0.009 & $1.28^{* *}$ & 0.015 & $1.89^{* * *}$ & $0.030^{* * *}$ \\
\hline $\begin{array}{l}\text { Primary tester of new } \\
\text { computer applications }\end{array}$ & $1.53^{* * *}$ & $0.041^{* *}$ & $1.49^{* * *}$ & 0.037 & $1.47^{* * *}$ & 0.033 \\
\hline $\begin{array}{l}\text { Applications } \\
\text { development }\end{array}$ & $1.29^{* * *}$ & 0.017 & $1.44^{* * *}$ & $0.034^{* * *}$ & $1.56^{* * *}$ & $0.013^{* * *}$ \\
\hline \multicolumn{7}{|l|}{ Learning by using } \\
\hline $\begin{array}{l}\text { Flexible versus fixed } \\
\text { schedule }\end{array}$ & 1.11 & 0.007 & $1.19^{* *}$ & 0.018 & $1.30 * * *$ & $0.010^{* *}$ \\
\hline Use of mobile tools & 1.08 & 0.022 & $1.24^{* * *}$ & $0.026^{* *}$ & $1.50^{* * *}$ & $0.019 * * *$ \\
\hline \multicolumn{7}{|c|}{ Collaborative and cooperative learning } \\
\hline $\begin{array}{l}\text { Internet use enhances } \\
\text { collaboration with } \\
\text { other students }\end{array}$ & $1.29^{* * *}$ & 0.022 & $1.42^{* * *}$ & $0.029 * *$ & $1.69 * * *$ & $0.018^{* * *}$ \\
\hline $\begin{array}{l}\text { Internet use improves } \\
\text { work presentation and } \\
\text { organization }\end{array}$ & 0.96 & -0.048 & $1.18^{*}$ & $0.029^{*}$ & $1.67^{* * *}$ & $0.031^{* * *}$ \\
\hline $\begin{array}{l}\text { Internet provides } \\
\text { business creation ideas }\end{array}$ & 1.15 & 0.002 & 1.12 & 0.006 & $1.73^{* * *}$ & $0.028^{* * *}$ \\
\hline $\begin{array}{l}\text { Internet provides } \\
\text { innovative ideas }\end{array}$ & 1.10 & 0.015 & $1.25^{* *}$ & $0.029^{*}$ & $1.28^{* * *}$ & 0.038 \\
\hline $\begin{array}{l}\text { Having the opportunity } \\
\text { to contact the teacher / } \\
\text { tutor by e-mail }\end{array}$ & $1.32^{* * *}$ & 0.025 & $1.47^{* * *}$ & $0.037^{* * *}$ & $1.42^{* * *}$ & 0.066 \\
\hline $\begin{array}{l}\text { Being able to } \\
\text { communicate and } \\
\text { discuss a course issues } \\
\text { online }\end{array}$ & 0.91 & -0.064 & $1.25^{* * *}$ & $0.052^{* * *}$ & $1.42^{* * *}$ & $0.021^{* * *}$ \\
\hline $\begin{array}{l}\text { Internet use enables } \\
\text { student to deepen the } \\
\text { content developed in } \\
\text { class }\end{array}$ & $1.19^{* *}$ & 0.014 & $1.37 * * *$ & $0.034^{* *}$ & $1.56^{* * *}$ & $0.056^{* * *}$ \\
\hline
\end{tabular}

Note: The notation $* * *, * *$, and $*$ denotes significance at the $1 \%, 5 \%$ and $10 \%$.

The parameter estimates indicate the impact of a unit change in the 
explanatory variables on log-odds ratios. The results confirm the expected signs of the coefficients of the students' characteristics and the ICT access. The results indicate that the student's characteristics, ICT access, the student's involvement, learning mechanisms, and collaborative and cooperative learning are crucial when explaining the probability that a student will be classified in one of the different categories of e-skills.

Table 6 shows that male students, ICT accessibility, ICT affordability, intensive learning by using, high collaborative and cooperative learning increase the probability of having information or strategic e-skills compared to the probability of having operational e-skills.

The associated negative values (effects) imply, in the case of the ESKILLS_2 category, that a unit increase of the variable of interest reduces the probability of having formal e-skills compared to the probability of having operational reference e-skills. In the case of the ESKILLS_3 category, a unit increase in the variable reduces the probability of having information e-skills compared to the probability of having operational e-skills.

The marginal effects (ME) and the odds-ratios (reported under the $\operatorname{Exp}(\beta)$ ) show the magnitude of the already identified increases. The estimation reveals that the student's gender has a statistically significant effect on the probability of having strategic e-skills. The estimated odds-ratio for male is 1.74 for ESKILLS_4 category suggesting that the predicted odds for a male, in order to be classified in the strategic e-skills category, increases by a multiplicative factor of 1.74 or, simply, that the change increases the odds of having strategic e-skills instead of having only operational e-skills by $74 \%$ in the considered category.

Regarding students' ages, older students are less likely to have all types of e-skills compared to relatively young ones (17-19 age group). This means that the older the students the more they are able to have operational skills. The coefficient for "24 years and more" is (-2.10), corresponding to an odds ratio of $12 \%$, thus indicating that the odds ratio in this category is lower than that in reference, which translates into an odds ratio below $1(27 \%, 23 \%$ and $12 \%$ for the 24 years and more age group in ESKILLS_2, ESKILLS_3 and ESKILLS_4 categories, respectively).

With regard to having a job while studying, a unit increase would multiply the odds of having ESKILLS_3 compared to having ESKILLS_1 by 1.49 and the odds of having ESKILLS_ 4 rather than ESKILLS 1 by 1.84 , implying an increase in the odds by $49 \%$ and $84 \%$ respectively.

With regard to ICT access, the availability of equipment tends to improve the probability of having information and strategic e-skills and mainly strategic ones. For instance, with regard to having a computer at home, an increase by one unit will significantly enhance the odds of having strate- 
gic e-skills compared to having operational e-skills by 3.69 implying almost threefold increase in odds. Furthermore, help and support have a positive and significant impact on having strategic e-skills compared to operational e-skills. An increase of one unit improves the odds by 1.26, which means an increase of $26 \%$ of strategic e-skills. Nevertheless, regarding "providing ICT training by the university"; an increase by one unit enhances significantly the odds of having formal e-skills compared to the reference category by 1.68 reflecting an increase of $68 \%$ of the odds of having formal e-skills.

\section{Student's involvement}

Regarding students' involvement, with respect to "ICT use training by students", an increase by one unit enhances significantly the odds of having information e-skills by 1.65 compared to operational e-skills implying an increase of $65 \%$ of the odds. With regard to time spent surfing on the Internet for learning purposes, the more the student spent time surfing, the higher the probability of having strategic e-skills compared to operational e-skills increases. For instance, the odds-ratio of 5.82 means that one additional student who spent more than 15 hours surfing on the Internet increases by almost six times the probability of having strategic e-skills compared to operational e-skills. Our estimates indicate how an operational change in the organization of higher education improves the acquisition of e-skills. Students' involvement by giving them the incentives to spend more time on Internet for pedagogical uses and for following courses related to ICT increase their probability to acquire e-skills. Moreover involvement impacts the nature of these e-skills. It allows students to acquire high level of e-skills (strategic and informational skills).

\section{Diversity of learning mechanisms}

With regard to learning mechanisms, ICT learning by doing has a significant and positive effect on all types of e-skills, e.g., application development increase by one unit raises significantly the odds of having respectively formal e-skills, information e-skills and strategic e-skills by $29 \%, 44 \%$ and $56 \%$ referring to operational e-skills.

Learning by using enhances significantly information and strategic e-skills compared to operational e-skills. For instance, one unit's increase of mobile use for studies multiplies the odds of having information and strategic e-skills by 1.24 and 1.50 respectively rather than operational e-skills, which means an increase of the odds by $24 \%$ and $50 \%$ respectively.

Again, these findings suggest the need for operational changes in universities to diversify the forms of learning mechanisms. This diversity of learning 
mechanisms improves the acquisition of all the forms of e-skills. At the same time we have seen their large impact on strategic skills.

\section{Collaboration and cooperation}

With regard to collaborative and cooperative learning, items in general reflect a positive and significant impact on the probability of having information and strategic e-skills compared to operational ones. In fact, with respect to students' views that Internet use enhances collaboration with other students, one unit increase multiplies the odds of having information e-skills and strategic e-skills by 1.42 and 1.69 respectively. In other words, the fact that Internet use enhances collaboration with others increases significantly the probability of having ESKILLS_3 and ESKILLS_4 by respectively $42 \%$ and $69 \%$. Furthermore, an increase in the belief that ICT gives students the opportunity to contact the teacher by e-mail by one unit multiplies the odds of having formal e-skills, information e-skills and strategic e-skills by respectively $1.32,1.47$ and 1.42 , which means an increase in the odds of $32 \%$, $47 \%$ and $42 \%$ respectively.

Again this suggests that organizational changes are correlated with the process of e-skills acquisition. Encouraging collaborative learning and improving cooperation between students through the use of ICT inside and outside the classroom allow them to acquire valuable e-skills (in particular, strategic skills).

\section{Summary of our three key findings}

Firstly, students' involvement increases the accumulation of their e-skills. The results of this study indicate that students' involvement enhances students' e-skills. ICT training enhances students' information e-skills. This could be explained by combining basic e-skills with learning through training based on ICT use leading to more sophisticated e-skills. Spending more hours surfing on the Internet for learning purpose also improves students' e-skills. Students who spend more time surfing on the Internet have more sophisticated e-skills.

Secondly, the diversity of learning processes enhances the accumulation of students' e-skills. The outcomes with regard to the relationships between learning processes and students' e-skills show the importance of ICT learning by doing and ICT learning by using to enhance e-skills. While ICT learning by doing enhances all types of e-skills, ICT learning by using enhances information e-skills and mainly strategic e-skills. This result shows the importance of using ICT tools to improve more sophisticated e-skills. Thus, strategies based on facilitating ICT learning by using are needed. These strategies could be reflected by letting students using ICT tools for learning 
purposes and letting them work in teams in order to use frequently distant tools (e.g. e-mail, videoconference...).

Thirdly, collaborative and cooperative learning facilitates the accumulation of students' e-skills. Since technological change and organizational change are considered to be complementary, effective ICT use at universities, as well as at firms, requires collaborative and cooperative competencies as both academic and professional environments undergo changes. When students understand that ICT tools facilitate communications between them and with teachers (which tends to improve the students' knowledge and then their performance) they tend to use ICT more often. This in turn enhances their more sophisticated e-skills.

\section{Concluding remarks}

The link between organizational change and the use of ICT allows students to acquire e-skills more efficiently. Internal organizational changes in universities are similar to those observed within modern firms (team work, project work, total quality, collaborative work, distance work, modular work, autonomy... ). Students improve their employability in the job market by acquiring organizational and e-skills at university.

The results of the multinomial logit model for French data from 2010 confirm the hypothesis of the existence of a correlation between organizational changes and e-skills acquired by students. In fact, our study contributes to a growing body of literature discussing students' e-skills accumulation. ICT integration in higher education has been steadily gaining interest over the past decade. However, challenges remain in implementing the right organizational changes in order to support the use of ICT and to enhance students' e-skills acquisition. Higher education institutions also may be blatantly or inadvertently blocking ICT development due to incoherent plans for inclusion and misunderstandings of the needed organizational changes. Our article has analysed how changes in the organization of learning can impact different types of e-skills acquisition by students and the nature of these skills. Further research is needed in order to extend the findings to other socio-cultural contexts.

\section{References}

Angrist, J. D., Lavy, V., 2002. New evidence on classroom computers and pupil learning. The Economic Journal 112 (482), 735-786. 
Arvanitis, S., Loukis, E. N., February 2009. Information and communication technologies, human capital, workplace organization and labour productivity: A comparative study based on firm-level data for greece and switzerland. Information Economics and Policy 21 (1), 43-61.

Askenazy, P., 2000. Innovations and employment: evidence from American manufacturing, 1st Edition. Routledge, London, Ch. 6, pp. 96-120.

Askenazy, P., Caroli, E., Marcus, V., 2002. New organizational practices and working conditions : Evidence from france in the 1990's. Recherches Économiques de Louvain / Louvain Economic Review 68 (1-2), 91-110.

Askenazy, P., Gianella, C., 2000. Le paradoxe de productivité : les changements organisationnels, facteur complémentaire à l'informatisation. Economie et Statistique 339 (1), 219-241.

Banerjee, A. V., Cole, S., Duflo, E., Linden, L., 2007. Remedying education: Evidence from two randomized experiments in india. Quarterly Journal of Economics 122 (3), 1235-1264.

Barak, M., Lipson, A., Lerman, S., 2006. Wireless laptops as means for promoting active learning in large lecture halls. Journal of Research on Technology in Education 38 (3), 245-263.

Ben Youssef, A., Hadhri, W., 2009. Les dynamiques d'usage des technologies de l'information et de la communication par les enseignants universitaires : le cas de la france. Réseaux 27 (155/2009), 25-54.

Black, S. E., Lynch, L. M., August 2001a. How to compete: The impact of workplace practices and information technology on productivity. The Review of Economics and Statistics 83 (3), 434-445.

Black, S. E., Lynch, L. M., 2001b. What's driving the new economy? the benefits of workplace innovation. Staff Reports 118, Federal Reserve Bank of New York.

Blass, E., 2005. The rise and rise of the corporate university. Journal of European Industrial Training 29 (1), 58-74.

Bocquet, R., Brossard, O., December 2007. The variety of ICT adopters in the intra-firm diffusion process: Theoretical arguments and empirical evidence. Structural Change and Economic Dynamics 18 (4), 409-437. 
Bresnahan, T. F., Brynjolfsson, E., Hitt, L. M., February 2002. Information technology, workplace organization, and the demand for skilled labor: Firm-level evidence. The Quarterly Journal of Economics 117 (1), 339-376.

Caroli, E., 2001. Organizational change, new technologies and the skill bias: What do we know? In: Petit, P., Soete, L. (Eds.), Technology and the Future of European Employment. Edward Elgar, pp. 259-292.

Caroli, E., Van Reenen, J., November 2001. Skill-biased organizational change? evidence from a panel of british and french establishments. The Quarterly Journal of Economics 116 (4), 1449-1492.

Ebner, M., Lienhardt, C., Rohs, M., Meyer, I., August 2010. Microblogs in higher education - a chance to facilitate informal and process-oriented learning? Computers and Education 55 (1), 92-100.

Fernandez, J. A., 2007. The future of corporate universities in europe. Global Focus 2 (2), 40-43.

Fonstad, N., Lanvin, B., 2009. Synthesis report for the european ecompetences curricula development guidelines project. Background report prepared by insead elab for the european business summit 2009, INSEAD eLab.

Franses, P. H., Paap, R., January 2001. Quantitative Models In Marketing Research, 1st Edition. Cambridge University Press, Cambridge.

Goldfarb, A., 2006. The Teaching role of Universities in the diffusion of Internet. International Journal of Industrial Organization 24 (2), 203-225.

Greenan, N., 1996. Progrès Technique et Changement Organisationnels: leur Impact sur l'Emploi et les Qualifications. Economie et Statistique 298 (1), $35-44$.

Greenan, N., Mairesse, J., 2004. A Firm Level Investigation of the Complementarity between Information and Communication Technologies and New Organizational Practices. In: 79th Annual conference of the Western Economic Association International. June 29-July 3, 2004. Vancouver, Canada.

Greenan, N., Walkowiak, E., May 2006. Information technology, work organisation and social interactions. Economie et Statistique 387, 35-63. 
Hair, J. F., Black, W. C., Babin, B. J., Anderson, R. E., 2006. Multivariate Data Analysis, 7th Edition. Pearson Prentice Hall, Upper Saddle River, New Jersey.

Hakkarainen, K., Ilomaki, L., Lipponen, L., Muukkonen, H., Rahikainen, M., 2000. Students skills and practices of using ict : Results of a national assessment in finland. Computers and Education 2, 103-117.

Hoskins, S. L., van Hooff, J. C., March 2005. Motivation and ability: which students use online learning and what influence does it have on their achievement? British Journal of Educational Technology 36 (2), 177-192.

Ichniowski, C., Shaw, K., Prennushi, G., June 1997. The effects of human resource management practices on productivity: A study of steel finishing lines. American Economic Review 87 (3), 291-313.

Jonassen, D., Lee, C. B., Yang, C.-C., Laffey, J., November 2005. The collaboration principle in multimedia learning. In: The Cambridge Handbook of Multimedia Learning. Richard Mayer, pp. 247-270.

Keengwe, J., Onchwari, G., Onchwari, J., 2009. Technology and student learning : Toward a learner- centered teaching model. AACE Journal $17(1), 11-22$.

Kezar, A. J., September 2001. Understanding and facilitating organizational change in the 21st century: recent research and conceptualizations, 1st Edition. Vol. 28 of J-B ASHE-ERIC Report Series (AEHE) Series. JosseyBass, Washington, DC.

Kolding, M., Kroa, V., 2007. E-skills: The key to employment and inclusion in europe. Tech. rep., IDC White Paper, London.

Lundberg, J., Dahmani, M., Castillo-Merino, D., 2008. Do online students perform better than face-to-face students? reflexions and a short review of some empirical findings. Revista de Universidad y Sociedad el Conociamento, RUSC 5 (1), 35-44.

Machin, S., McNally, S., Silva, O., 2007. New technology in schools: Is there a payoff? Economic Journal 117 (522), 1145-1167.

Maddala, G. S., 1993. Limited-Dependent and Qualitative Variables in Econometrics. Cambridge University Press, Cambridge.

Malhotra, N. K., July 2009. Marketing Research: An Applied Orientation. Prentice Hall, Upper Saddle River, New Jersey. 
Nicol, D. J., MacLeod, I. A., May 2005. Using a shared workspace and wireless laptops to improve collaborative project learning in an engineering design class. Computers and Education 44 (4), 459-475.

Nunnally, J., Bernstein, I., January 1994. Psychometric theory, 3rd Edition. McGraw-Hill, New York.

OECD, 2006. Education Policy Analysis: Focus on Higher Education. OECD, Paris.

Pavitt, K., 1985. Patent statistics as indicators of innovative activities: Possibilities and problems. Scientometrics 7 (1,2), 77-99.

Rivkin, S. G., Hanushek, E. A., Kain, J. F., 2005. Teachers, schools, and academic achievement. Econometrica 73 (2), 417-458.

Saulnier, B. M., Landry, J. P., Longenecker, H. E., Wagner, T. A., 2008. From teaching to learning : Learner-centered teaching and assessment in information systems education. Journal of Information Systems 19 (2), $169-175$.

SEUSISS Project Final Report, 2003. Survey of european universities skills in ict of students and staff. Tech. rep.

Sharma, S., October 1995. Applied Multivariate Techniques. John Wiley and Sons, Inc, New York.

Sivapalan, S., Cregan, P., 2005. Value of online resources for learning by distance education. CAL-laborate 14, 23-27.

Steyaert, J., 2002. Inequality and the digital divide: myths and realities. In: McNutt, S. H. . J. (Ed.), Advocacy, activism and the internet. Lyceum Press., Chicago, pp. 199-211.

Su, K.-D., 2008. An integrated science course designed with information communication technologies to enhance university students' learning performance. Computers and Education 51 (3), 1365-1374.

Thijs, A., Almekinders, R., Blijleven, P., Pelgrum, W., Voogt, J., 2001. Learning through the web: a literature study on the potential uses of the web for student learning. Tech. rep., University of Twente, Faculty of Educational Science and Technology, Department of Curriculum, Enschede.

Triplett, J. E., April 1999. The solow productivity paradox: what do computers do to productivity? Canadian Journal of Economics 32 (2), 309-334. 
Tuparovaa, D., Tuparova, G., 2010. Automated real-live performance-based assessment of ict skills. Procedia - Social and Behavioral Sciences 2 (2), $4747-4751$.

van Deursen, A. J. A. M., van Dijk, J. A., 2010. Measuring internet skills. International Journal of Human-Computer Interaction 26 (10), 891-916.

van Dijk, J. A., February 2005. The Deepening Divide Inequality in the Information Society. Sage Publications, Thousand Oaks, California.

van Dijk, J. A., August-October 2006. Digital divide research, achievements and shortcomings. Poetics 34 (4-5), 221-235.

Zammit, L., 2004. Literacy in ict skills. Tech. rep., The Lisbon Objectives and the Maltese Education Provision. 